\title{
Differentiation of soil organisms at different types of peatland in West Kalimantan, Indonesia
}

\author{
ROSSIE WIEDYA NUSANTARA`, ASRIPIN ASPAN \\ Department of Soil Science, Faculty of Agriculture, Tanjungpura University. Jl. Prof Hadari Nawawi, Pontianak 78124, West Kalimantan, Indonesia \\ "email: rwiedyanusantara@gmail.com
}

Manuscript received: 2 February 2017. Revision accepted: 27 June 2017

\begin{abstract}
Nusantara RW, Aspan A. 2017. Differentiation of soil organisms at different types of peatland in West Kalimantan, Indonesia. Bonorowo Wetlands 7: 26-30. Peatland conversion could threaten the soil organisms' existence which is influenced by soil physical properties. This research aimed to analyze the changes in soil organisms of land use due to the conversion of peatlands in West Kalimantan, Indonesia. The study was conducted in secondary peat forest (SPF), shrub (SB), oil palm plantation (OPP), and cornfield (CF) in Kubu Raya District of West Kalimantan. The stages in this study include observation of water-table depth soil temperature and analysis of physical properties, including bulk density, moisture, and porosity. The results indicated a decline in colonies of bacteria and fungi in OPP than SPF, 50\% and 53\%, respectively. The condition of affected water content decreases due to the land conversion of secondary forests into oil palm plantations $(22.8 \%)$. Additionally, conditions on the water-table depth were deeper, and soil temperature was higher in OPP than SPF (16.8\%). This condition was the opposite in CF, where both bacteria and fungi increased 53\% and 33.3\%, respectively. The water content, water-table depth, and bulk density were characterized by the different conditions even though the temperature was almost the same between OPP and CF.
\end{abstract}

Keywords: soil organisms, land-use change, water content, bulk density, water-table depth

\section{INTRODUCTION}

The world's tropical peatlands are around 38 million hectares, mostly located in Indonesia (14.9 million hectares) (BBPPSDLP 2011). Peat swamp forest is one type of wetland most endangered in Indonesia due to pressure from human activities. Forest conversion to agricultural land and forest production can threaten the existence of natural peat swamp forests. Activities in the area of cultivation include land clearing, such as the felling of trees (deforestation), slashing the bushes and the burning remnants of vegetation, creation of drainage channels, soil compaction for land preparation and manufacture of ridges (Radjagukguk 2000; Page et al. 2009; Wösten et al. 2008; Hooijer et al. 2010). Peatland degradation occurs through deep drainage and uncontrolled combustion.

Burning the land as a form of accelerated oxidation can result in loss of soil organic matter of peat and leaching of soil nutrients due to increased decomposition of peat and soil micro-organisms death. Temperature between $40-70^{\circ} \mathrm{C}$ can lead to the destruction of biological tissue, At the temperature range of $70-90^{\circ} \mathrm{C}$, seeds begin dying, and microbial death occurs between $50-120^{\circ} \mathrm{C}$ (Hernandez et al., 1997). Making the edafon land devastated by fire damage (flora and fauna). After the fire activity, the number of bacteria increased in some specific forest land. The increase in activity and the number of soil bacteria, and the growth of legumes encourage nitrification (Notohadoprawiro 2006). On the other hand, another biophysical result of fires is encouraging nitrogen $(\mathrm{N})$ leaching and polluting water bodies with nitrates. Instead of fires no good effect on soil macrofauna, especially earthworms. Earthworms do not like high temperatures and drought-related land with a high temperature (Chandler et al. 1983). Based on differences in soil conditions due to changes in land use. It is necessary to study the details of differentiation of soil biology in several types of peatland due to land-use change. So, with the study expected their efforts for the prevention, mitigation, and recovery to preserve peat awake.

\section{MATERIALS AND METHODS}

\section{Study area}

The study area was four peatland types, namely secondary peat forest (SPF) $\left(00^{\circ} 21.70^{\prime} \mathrm{S}, 109^{\circ} 21.81^{\prime} \mathrm{E}\right)$, shrubs (SB) $\left(00^{\circ} 21.42^{\prime} \mathrm{S}, 1^{\circ} 29^{\circ} 21.51^{\prime}\right.$ E), oil palm plantation (OPP) $\left(00^{\circ} 23.87^{\prime} \mathrm{S}, 109^{\circ} 22.65^{\prime} \mathrm{E}\right)$ and corn-field (CF) $\left(00^{\circ} 23.87^{\prime} \mathrm{S}, 109^{\circ} 22.65^{\prime} \mathrm{E}\right)$ in Kubu Raya District, West Kalimantan, Indonesia. Soil sampling was conducted in May 2016.

\section{Measurement of water-table depth and soil temperature}

At each sampling point, water-table depth was measured by the distance of groundwater to the soil's surface. Soil temperature data were taken using a digital thermometer inserted into the ground.

\section{Soil sampling and sample analysis}

Samples were taken from three sampling points at each land location as replication. Peat soil sampling in the 
topsoil $(0-20 \mathrm{~cm})$. Soil samples were dried aired for approximately one to two days. Then the soil was separated from the roots of plants, gravel, and other debris. After setting up a soil sample with a size of $<2 \mathrm{~mm}$ and $<0.5 \mathrm{~mm}$, the sample was weighed using pulverized and sieved to prepare the soil sample for analysis. Analysis of biological characteristics as the main parameter in total bacteria and fungi using total plate count (TPC). The physical features of the parameters include water content, bulk density, and porosity. Analysis of the contents by weight 'literan' method (tube servings) and soil porosity with the calculation method of BD and BJ. BJ measurements while using a pycnometer, the water content of the difference between wet weight and dry weight of soil.

\section{Data analysis}

Regression analysis was carried out using SPSS 2.1 to determine the relationship between the total bacteria and fungi and water-table depth, water content, bulk density, porosity, and temperature.

\section{RESULTS AND DISCUSSION}

Biological analysis of soil as the main parameters such as type and total of bacteria and fungi. The physical characteristic of soil as supporting parameters include water content, bulk density, and porosity to the water-table depth and soil temperatures (Table 1 and 2).

The population of bacteria and fungi on the study site varies. In SPF (as a control) has three species of bacteria, respectively of $14 \times 10^{5} \mathrm{cfu}, 2 \times 10^{5} \mathrm{cfu}$ and $1 \times 10^{5} \mathrm{cfu}$. The total of bacterial are highest in the CF, three species of bacteria each $24 \times 10^{5} \mathrm{cfu}, 1 \times 10^{5} \mathrm{cfu}$, and $1 \times 10^{5} \mathrm{cfu}$, respectively. While OPP is the lowest, the two species of bacteria are $3 \times 10^{5} \mathrm{cfu}$ and $2 \times 10^{5} \mathrm{cfu}$. Similar to the type and total fungi in SPF has two types of fungi (Rhizopus sp. and Penicillium sp.) With a total of fungi, each $1 \times 10^{5} \mathrm{cfu}$ and $5 \times 10^{5} \mathrm{cfu}$. The type and number of fungi are the highest in CF with 3 types (Fusarium sp., Rhizopus sp. and Penicillium sp.) that each $2 \times 10^{5} \mathrm{cfu}, 5 \times 10^{5} \mathrm{cfu}$, and $1 \mathrm{x}$ $10^{5} \mathrm{cfu}$. At the same time, OPP has 1 type (Rhizopus sp.), 1 $\mathrm{x} 10^{5} \mathrm{cfu}$. The decrease in total bacteria and fungi in OPP than SPF, 50\% and 53\%, respectively.

The existence and diversity of soil microorganisms are affected by physical conditions such as water table depth and soil temperature. There is a strong negative correlation between the water-table depth and total bacteria and fungi with $r$ between 0.816 and 0.872 (Figure 1a-b). In contrast to the temperature, there is a weak correlation with the total bacteria and fungi ( $\mathrm{r}$ between 0.074 and 0.151) (Figure 1.CD).

Table 1. The population of bacteria and fungi at secondary peat forest, shrubs, oil palm plantations, and corn-field in West Kalimantan Peatland, Indonesia

\begin{tabular}{|c|c|c|c|c|c|}
\hline Type of land & $\begin{array}{l}\text { Type } \\
\text { bacteria }\end{array}$ & of & $\begin{array}{l}\text { Total of bacteria } \\
\left(10^{5} \mathrm{cfu}\right)\end{array}$ & Fungi & $\begin{array}{l}\text { Total of fungi } \\
\left(10^{5} \mathrm{cfu}\right)\end{array}$ \\
\hline \multirow[t]{3}{*}{ Secondary peat forest (SPF) } & Sp 1 & & 14 & Rhizopus & 1 \\
\hline & Sp 2 & & 2 & Penicillium & 5 \\
\hline & Sp 3 & & 1 & - & - \\
\hline Shrubs (SB) & Sp 1 & & 11 & Penicillium & 4 \\
\hline \multirow[t]{2}{*}{ Oil palm plantations (OPP) } & Sp 1 & & 3 & Rhizopus & 1 \\
\hline & Sp 2 & & 2 & - & - \\
\hline \multirow[t]{3}{*}{ Corn-field (CF) } & Sp 1 & & 24 & Fusarium & 2 \\
\hline & Sp 2 & & 1 & Penicillium & 5 \\
\hline & Sp 3 & & 1 & Aspergillus & 1 \\
\hline
\end{tabular}

Note: Sp 1 = form circular, convex slope, entire edge, white, smooth, shiny surface. Sp 2 = irregular shape, slope raised, undulating edge, white, smooth, shiny surface. Sp3 = circular shape, the slope of the flat, edge entire, transparent color, dull surface.

Table 2. Water-table depth (WTD, water content, bulk density, porosity, and temperature at secondary peat forest, shrubs, oil palm plantations, and corn-field in West Kalimantan Peatland, Indonesia

\begin{tabular}{llllll}
\hline Type of land & $\begin{array}{l}\text { WTD } \\
(\mathbf{c m})\end{array}$ & $\begin{array}{l}\text { Water content } \\
(\boldsymbol{\%})\end{array}$ & $\begin{array}{l}\text { Bulk density } \\
\left(\mathbf{g ~ c m} \mathbf{~ c m}^{-3}\right)\end{array}$ & Porosity $(\boldsymbol{\%})$ & Temperature $\left({ }^{\circ} \mathbf{C}\right)$ \\
\hline Secondary peat forest (SPF) & 34.13 & $90.40 \pm 6.60$ & $0.14 \pm 0.03$ & $95.78 \pm 0.78$ & 22.78 \\
Shrubs (SB) & 35.75 & $41.93 \pm 9.05$ & $0.16 \pm 0.02$ & $94.90 \pm 2.25$ & 27.78 \\
Oil palm plantations (OPP) & 41.00 & $35.56 \pm 10.95$ & $0.22 \pm 0.04$ & $94.21 \pm 2.15$ & 27.22 \\
Corn-field (CF) & 29.50 & $66.88 \pm 2.98$ & $0.6 \pm 0.02$ & $95.40 \pm 0.63$ & 26.44 \\
\hline
\end{tabular}




\section{Water-table depth and temperature on the diversity of soil microbes}

The deeper the water-table depth, especially on intensive agricultural, causing microorganism population decline. It is characterized by low water content (Figure 2 . A-B) despite a weak positive correlation between the water content and the total bacteria and fungi ( $\mathrm{r}$ between 0.305 and 0.239). The same research shows Mishra et al. (2016) that variations most influence microbial profiles from peatland sites in water-table and land-use patterns. Oil palm plantation monocultures supported the least diverse bacterial communities. On the other hand, mixed crop plantations consisting of up to only five plant species supported the most diverse bacterial communities. Agree with Hadi et al. (2001) that land conversion from secondary forest to paddy fields (monoculture plantations) led to a decrease in carbon content, together with a decrease in microbial abundance, which is consistent with these findings. This study shows that low bacterial diversity in OPP can be sensitive to environmental pressures.

\section{Soil physical characteristic on the diversity of soil microbes}

The physical characteristics of the soil influence the existence of soil organisms. The decline in soil bacteria and fungi in OPP affected water content reduction due to the land conversion of SPF into OPP; however, their relationship is weak (r 0.305 and 0.239 ) (Figure 2. A-B). The decline marked by the water-table depth in OPP is deeper $(16.8 \%)$, and the soil temperature is higher $(16.3 \%)$ (Table 2, Figures 1 and 2). This condition is the opposite in
$\mathrm{CF}$, where there is an increase in the total of bacteria and fungi, $53 \%$ and $33.3 \%$, respectively. Different conditions are characterized by the shallow water-table depth (13.6\%) and the high-water content $(12.7 \%)$ (Table 2). There is a very weak correlation between the water content and the total bacterial and fungi; $r 0.305$ and 0.239 . There is a strong positive correlation between bulk density, porosity, and a total of bacteria and fungi, $r$ between $0.630,0.765$, 0.584, and 0,496, respectively (Figure 2. C-D and 2. E-F).

Overall findings indicate that $\mathrm{CF}$ has the highest of bacteria and fungi. This is likely due to factors of high bulk density $\left(0.6 \mathrm{~g} \mathrm{~cm}^{-3}\right)$ and moderate water content $(66.88 \%)$, while other lands such as OPP have a low bulk density $\left(0.22 \mathrm{~g} \mathrm{~cm}^{-3}\right)$ and water content $(35.56 \%)$. They are increasing the number of soil microbes in CF allegedly due to land management in regularly burning and fertilizing before planting. Results of interviews with local farmers showed that before corn planting is done, burning vegetation such as shrubs and above-ground plant residues of corn to get ash and fertilizers such as urea, SP36, and $\mathrm{KCl}$. The existence of these additional elements into a source of nutrients and energy for the activity and growth of microbes in the soil. Contrary to Yule et al. (2016), the fire significantly impacted the microbial community composition. Degradation and burning caused a marked decrease in most Acidobacteria, apart from Koribacteraceae. The same explanation by Wasis et al. (2012) that the number of soil microbes decreases after the fire, but expected to happen temporarily and will go back to normal.

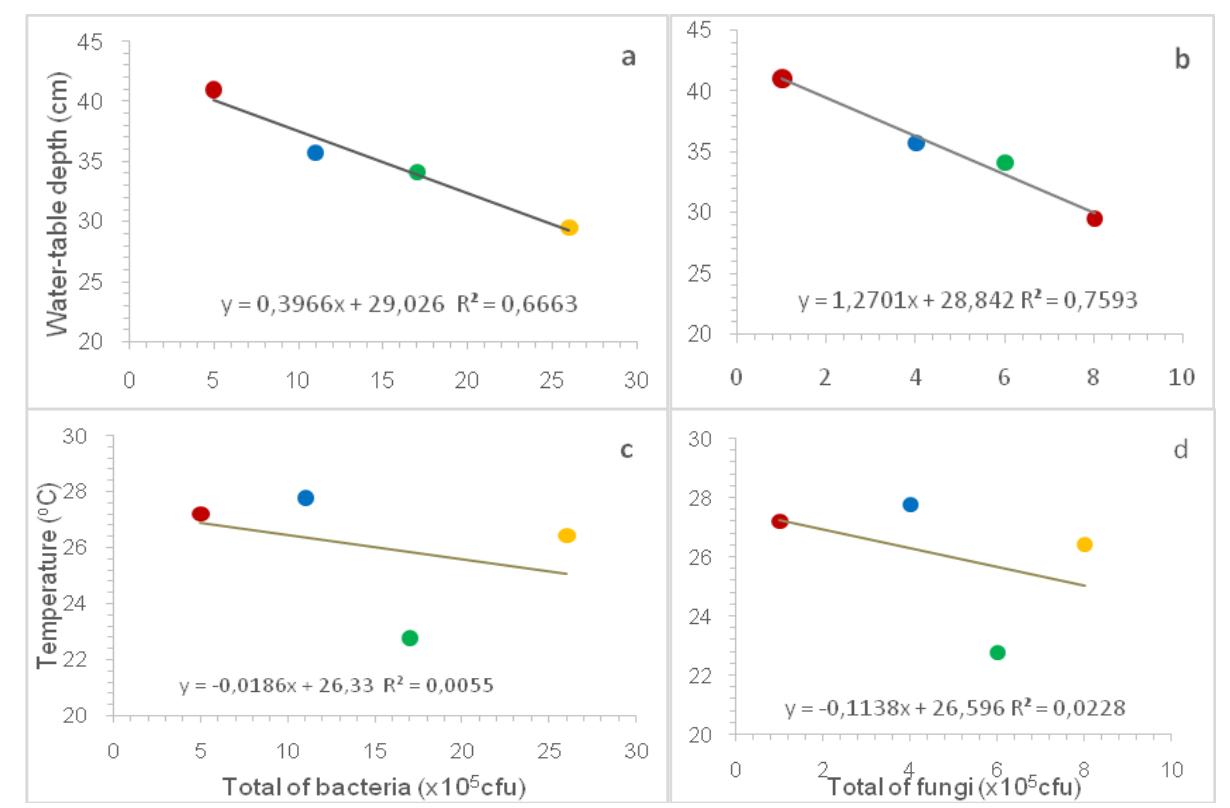

Figure 1. Correlation between the water-table depth (A-B), temperature (C-D) and) and a total of bacteria and fungi of peatland as the effect of land-use change. The green, blue, orange, and red circles show the land of SPF, SB, CF, and OPP, respectively. 


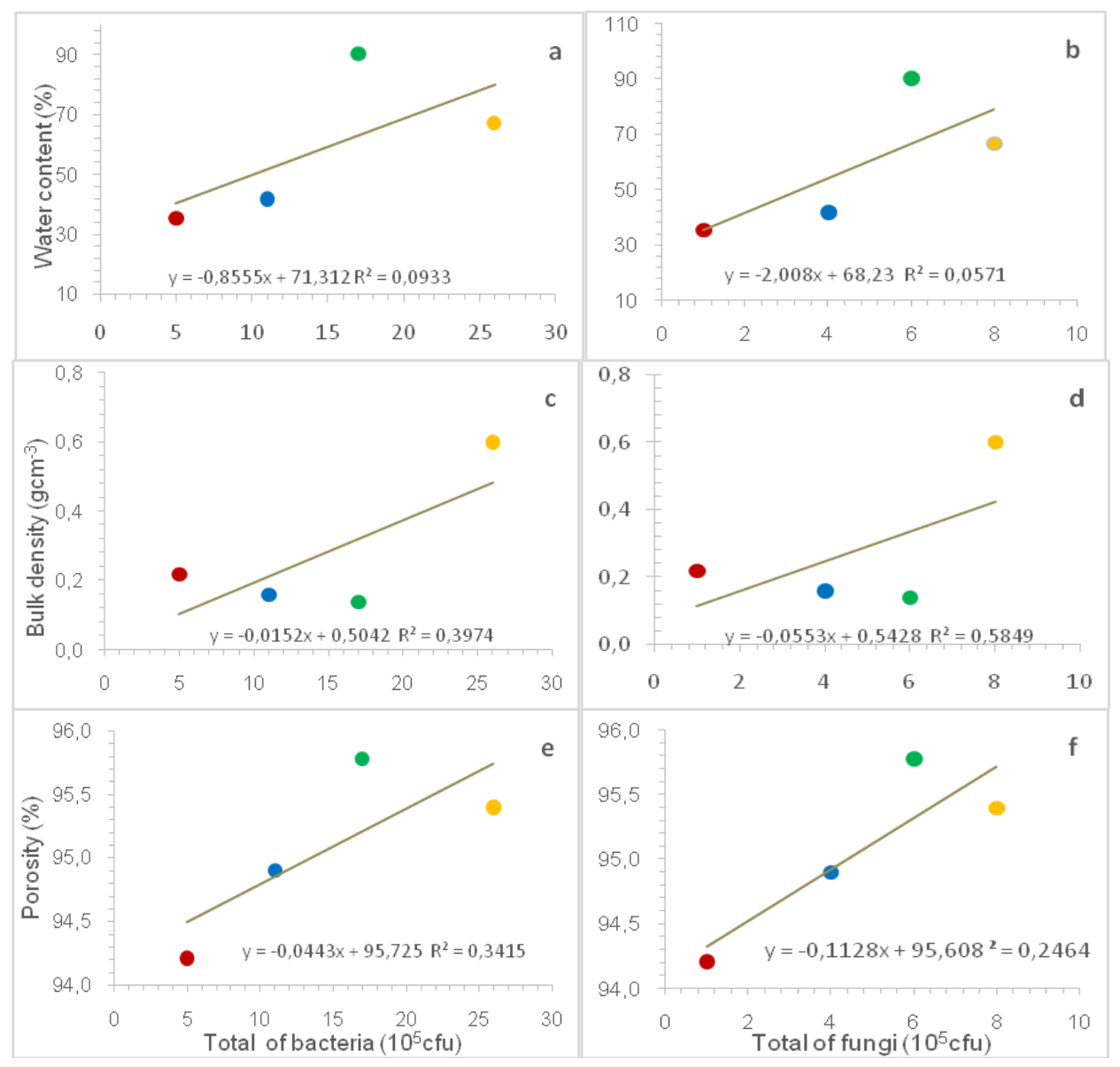

Figure 2. Correlation between water content (A-B), bulk density (C-D), porosity (E-F), and the total of bacteria and fungi of peatland as the effect of land-use change. The green, blue, orange, and red circles show the land of SPF, SB, CF, and OPP, respectively.

Peatland-use change caused changes in soil physical characteristics such as increased bulk density and soil temperature and decreased water-table depth, water content, and porosity. Changes in water content, bulk density, and porosity of the soil were positively correlated, in contrast to water-table depth, to the soil microbes (bacteria and fungi). This study provides baseline information about the microbial diversity in forestry and agricultural landscapes. The data is helpful to highlight the conservation value of those landscapes for microbes.

\section{ACKNOWLEDGEMENTS}

This work was financially supported by the DIPA of Faculty of Agriculture, Universitas Tanjungpura, Pontianak, Indonesia (2016). Mainly thanks to the Laboratory of Soil Chemistry and Fertility staff, Faculty of Agriculture, Universitas Tanjungpura and M. Nuriman, Ahon, Rio, Randi, Erik, Yenni, and Putri for their help at laboratory and field.

\section{REFERENCES}

BBPPSDLP [Balai Besar Penelitian dan Pengembangan Sumber Daya Lahan Pertanian]. 2011. Peta Lahan Gambut Indonesia Skala 1:250.000. Indonesian Agency for Agricultural Research and Development, Jakarta. [Indonesian]

Chandler C, Cheney P, Thomas P, Trabaud L, Williams D. 1983. Fire in Forestry, Volume I: Forest Fire Behavior and Effects. John Wiley and Sons, Inc., New York.

Hadi A, Haridi M, Inubushi K, Purnomo E, Razie F, Tsuruta H. 2001. Effect of land-use change in tropical peat soil on microbial population and emission of greenhouse gasses. Microbes Environ 16 (2): 79-86. DOI: $10.1264 /$ jsme2.2001.79.

Hernandez T, Garcia C, Reinhardt I. 1997. Short-term effect of wildfire on the chemical, biochemical and microbiological properties of Mediterranean pine forest soils. Biol Fertil Soil 25 (2): 109-116. DOI: 10.1007/s003740050289.

Hooijer A, Page S, Canadell JG, Kwadijk J, Wösten H, Jauihianen J. 2010. Current and future $\mathrm{CO}_{2}$ emissions from drainaed peatland in Southeast Asia. Biogeosciences 7 (5): 1505-1514. DOI: 10.5194/bg7-1505-2010.

Mishra S, Mishra S, Yi YP, Shivshankar U, Moses D Idris A, Schuster S, Swarup S. 2016. Developing sustainable practice to mitigate impacts of climate change $\mathrm{n}$ natural and managed tropical peatlands. 15th International Peat Congress 2016. Kuching, Sarawak, Malaysia.

Notohadiprawiro T. 2006. Pembakaran dan kebakaran lahan. Prosiding Simposium Dampak Kebakaran Huan terhadap Sumber Daya Alam dan Lingkungan, Yogyakarta, 16-17 Desember 1997. 
Soil.blog.ugm.ac.id/files/206/11/1991-Pembakaran-dan-Kebakaran Lahan.pdf [Indonesian]

Page SE, Hoscilo A, Wösten H, Jauhiainen J, Silvius M, Rieley J, Ritzema H, Tansey K, Graham L, Vasander H, Limin S. 2009. Restoration ecology of lowland tropical peatlands in Southeast Asia: Current knowledge and future research directions. Ecosystems 12 (6): 888 905. DOI: $10.1007 / \mathrm{s} 10021-008-9216-2$.

Radjagukguk B. 2000. Perubahan sifat-sifat fisik dan kimia tanah gambu akibat reklamasi lahan gambut untuk pertanian. Jurnal Ilmu Tanah dan Lingkungan 2 (2000): 1-15. [Indonesian]
Wasis B, Setiadi Y, Purwanto ME. 2012. Sifat kimia dan biologi tanah akibat keterbukaan lahan pada hutan reboisasi pinus di Kecamtan Pollung Kabupaten Humbang Hasundutan Sumatera Utara. Jurnal Silvikultural Tropika 3 (1): 33-36. [Indonesian]

Wösten JHM, Clyman SE, Page SE, Rieley JO, Limin SH. 2008. Peatwater interrelation in tropical peatland ecosystem in Southeast Asia. Catena 73 (2): 201-217. DOI: 10.1016/j.catena.2007.07.010.

Yule C M, Evers S, Smith T, Gan H M, Too1 C C, Eng WH. 2016. Impact of fire on microbial diversity and community structure in Malaysian Peatlands. 15th International Peat Congress 2016. Kuching, Sarawak, Malaysia. 